Original Article

\title{
Comparative anatomical studies on the cranial nerves of the fully formed embryos of the Nile tilapia Oreochromis niloticus (Ostiechthyes-Cichlidae). I. Nervus glossopharyngeus
}

\author{
Estudos anatômicos comparativos dos nervos cranianos de embriões totalmente \\ formados da tilápia do Nilo Oreochromis niloticus (Ostiechthyes-Cichlidae). I. Nervus \\ glossopharyngeus
}

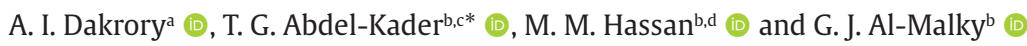 \\ aCairo University, Faculty of Science, Department of Zoology, Cairo, Egypt \\ 'Taif University, College of Sciences, Department of Biology, Taif, Saudi Arabia \\ 'Helwan University, Department of Zoology \& Entomology, Faculty of Science, Cairo, Egypt \\ ${ }^{\mathrm{d} A i n}$-Shams University, Department of Zoology, Faculty of Science, Cairo, Egypt
}

\begin{abstract}
The organization of the roots, ganglia and the peripheral distribution of the cranial nerves of the fully formed embryos of Oreochromis niloticus are examined in the transverse serial sections. These nerves carry fibers, which were also analyzed. The results of this study demonstrated that the glossopharyngeal nerve originates by means of only one root, which leaves the cranium through the glossopharyngeal foramen. This nerve gives fibers (visceromotor) to the first internal and external levator arcus branchialis muscles. There is a single epibranchial (petrosal) ganglion located extracranially. Nervus glossopharyngeus has three rami; pharyngeus, pretramticus and posttrematicus. The ramus pharyngeus carries only viscerosensory fibers; general for the pharyngeal epithelium and special ones for the pseudobranch. General viscerosensory fibers are also carried by rami pretrematicus and posttrematicus for the pharyngeal epithelial lining. The special sensory fibers are carried by the ramus pretrematicus for the taste buds and by ramus posttrematicus for the gill filaments. The ramus pretrematicus also carries visceromotor fibers for the first adductor arcus branchialis and to the first obliquus ventralis muscles.
\end{abstract}

Keywords: Osteichthyes, Cichlidae, Oreochromis niloticus, Nervus Glossopharyngeus.

\begin{abstract}
Resumo
A organização das raízes, gânglios e a distribuição periférica dos nervos cranianos dos embriões totalmente formados de Oreochromis niloticus são examinados nas seções transversais seriais. Esses nervos carregam fibras, que também foram analisadas. Os resultados deste estudo demonstraram que o nervo glossofaríngeo se origina por meio de apenas uma raiz, que sai do crânio pelo forame glossofaríngeo. Este nervo fornece fibras (visceromotoras) para os primeiros músculos levantadores do arco branquial interno e externo. Existe um único gânglio epibranquial (petroso) localizado extracranialmente. Nervus glossopharyngeus tem três ramos; faríngeo, pretramticus e póstrematicus. 0 ramo faríngeo contém apenas fibras viscerossensoriais - gerais para o epitélio faríngeo e especiais para o pseudobrânquio. Fibras viscerossensoriais gerais também são transportadas por ramos pretrematicus e posttrematicus para o revestimento epitelial da faringe. As fibras sensoriais especiais são transportadas pelo ramus pretrematicus para as papilas gustativas e pelo ramus posttrematicus para os filamentos branquiais. O ramo pretrematicus também carrega fibras visceromotoras para o primeiro adutor arcus branchialis e para o primeiro músculo oblíquo ventral.
\end{abstract}

Palavras-chave: Osteichthyes, Cichlidae, Oreochromis niloticus, Nervus Glossopharyngeus.

\section{Introduction}

The organization of gill innervation is discussed briefly (Nilsson, 1984; Sundin and Nilsson, 2002; Dakrory et al., 2014, 2018). However, the gill region is only innervated by nervi facialis, glossopharyngeus and vagus so they are called the branchial nerves (Jonz and Nurse, 2008). In teleost fishes, the nervi glossopharyngeus and vagus primarily innervate the gill arches. Branches of the branchial nerves are further divided into pretrematic (anterior) and posttrematic (posterior) rami that straddle the gill slits (Nilsson, 1984; Sundin and Nilsson, 2002; Jonz and Nurse, 2008).

The recent studies performed on bony fishes are presented by some other authors such as the study made by

*e-mail: tharwat301@gmail.com

Received: November 11, 2020 - Accepted: January 6, 2021 
Dakrory (2003) on the ciliary ganglion and its anatomical relations in some bony fishes. Sneddon (2003) examined the trigeminal somatosensory innervation of the head of a teleost fish, Oncorhynchus mykiss. In addition, Kerem et al. (2005) described the somatotopic organization of the trigeminal ganglion cells in a cichlid fish, O. niloticus. Meader (2005) gave an account on the innervation of the muscle of accommodation in the eye of the teleost fish, Holocentrus ascensionis. Ali and Dakrory (2008) studied the eye muscle nerves of Alticus kirkii magnosi.

Moreover, the most recent studies including the species under investigation interested in some other topics other than anatomy, such as behavioral and ecophysiological studies made by. Saparuddin et al. (2020) and Abougabal et al. (2020).

It is proved from the aforementioned review that, there are numerous studies performed on the cranial nerves of bony fishes. However, few studies were done on the cranial nerves of members belonging to the family Cichlidae. Therefore, the present study aimed to show the anatomy of the glossopharyngeal nerve of one species belongs to this family. Also, it is very important to make a full analysis for the fibers of this nerve, distribution and its relation with the other head structures.

\section{Materials and Methods}

The studied species is a freshwater bony fish; Oreochromis niloticus belonging to the family Cichlidae. O. niloticus is a diurnal and omnivorous fish that feeds on phytoplankton, aquatic plants, small invertebrates and benthic fauna. It is widely known for its importance in aquaculture.

The specimens of this species (fully formed embryos) were collected from a Nile tributary near Abu-Rawash. The fixation of the heads was in an aqueous Bouin solution for 24 hours. This is followed by washing in $70 \%$ ethyl alcohol several times and with distilled water to remove the excess of Bouin solution (AL-Malki, 2017).

The heads were decalcified by placing them in EDTA solution for about 40-45days, with changing the solution every 4 days. Then staining in toto for this bony species was carried out with Borax carmine after which they were prepared for blocking and then sectioned transversely by microtome (10 microns in thickness) (Dakrory et al., 2018). An accurate graphic reconstruction for the glossopharyngeal nerve was made in a lateral view after drawing of the serial transverse sections with the help of the projector (Dakrory et al., 2018). Many photomicrographs of parts of the sections were taken for illustration.

\section{Results}

The glossopharyngeal nerve of 0 . niloticus (Figures 1,2 , RO.IX) originates by means of one root from medulla oblongata at its ventrolateral side just ventral to the root of the posterior lateral line nerve. Nervus glossopharyngeus, after its origin, runs posteriorly in a ventrolateral direction intracranially. After a short distance, it emerges from the cranium through the glossopharyngeal foramen (Figure 3, F.GP). This foramen occupies a position in the anterior part of the exoccipital bone (EXO.), anterior and medial to the jugular foramen. Immediately outside the cranial cavity, the glossopharyngeal nerve gives off a dorsal communicating branch to the Cranial Sympathetic Nerve (Figure 1, R.CM. IX+N.CSY). This branch and the main nerve together run forwards medial to both the cranial sympathetic nerve and the ganglion of the first branchial vagal trunk $\left(G . E B . X_{1}\right)$, lateral to the cranial sympathetic nerve and dorsal to the internal jugular vein (IJV.) (Figure 4). Here, the cranial sympathetic nerve fuses with the dorsal branch and anastomoses with the main glossopharyngeal nerve. Thereafter, nervus

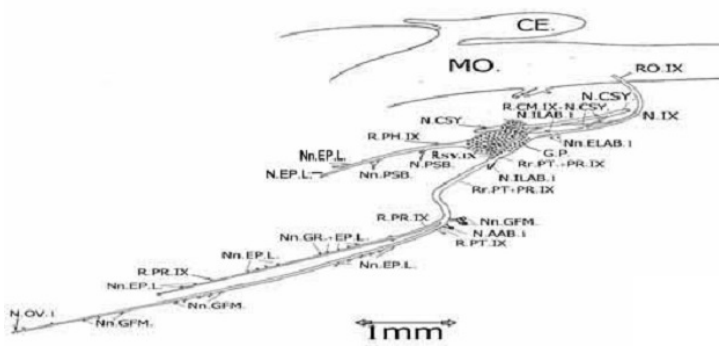

Figure 1. Graphic reconstruction of nervus glossopharyngeus of Oreochromis niloticus in a lateral view. CE. Cerebellum. G.P. Petrosal ganglion. MO. Medulla Oblongata. N.AAB.1 Nerve to the $1^{\text {st }}$ adductor arcus brachialis muscle. N.CSY. Cranial sympathetic nerve. N.EP.L. Nerve to the epithelial lining. N.ILAB.1 Nerve to the $1^{\text {st }}$ internal levator arcus branchialis muscle. N.OV.1 Nerve to the $1^{\text {st }}$ obliquus ventralis muscle. N.PSB. Nerve to pseudobranch. N.IX Nervus glossopharyngeus Nn.ELAB.1 Nerves to the first external levator arcus branchialis muscle. Nn.EP.L. Nerves to the epithelial lining. Nn.GFM. Nerves to the gill filament muscles. Nn.Gr.+EP.L. Nerves for gill rakers and the epithelial lining. Nn.PSB. Nerves to the pseudobranch. R.CM.IX+N.CSY. Ramus communicans of the glossopharyngeal nerve and the cranial sympathetic nerve. R.PH.IX Ramus pharyngeus of nervus glossopharyngeus. R.PR. IX Ramus pretrematicus of nervus glossopharyngeus. R.PT.IX Ramus posttrematicus of the glossopharyngeal nerve. R.SY.IX Ramus sympathetic connecting the glossopharyngeal nerve. RO.IX Glossopharyngeal root. Rr.PT.+PR.IX Rami posttrematicus and pretrematicus of the glossopharyngeal nerve.

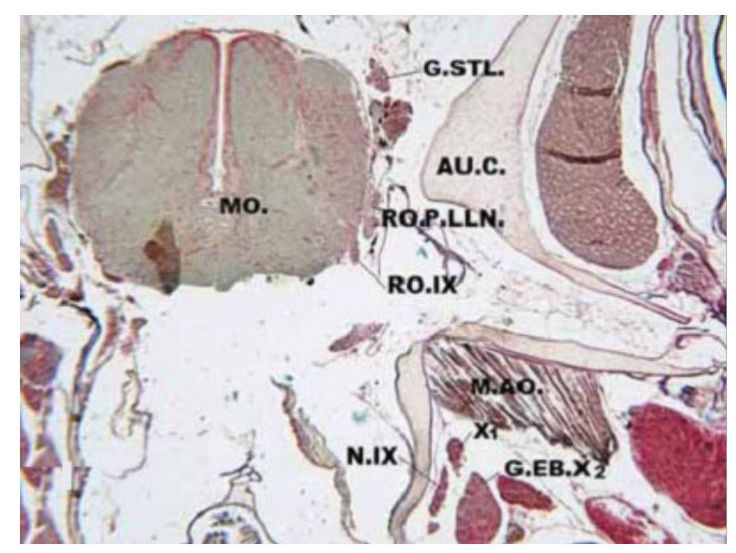

Figure 2. Photomicrograph of part of a transverse section of Oreochromis niloticus passing through the postorbital region showing the origin of the root of nervus glossopharyngeus. X40. 


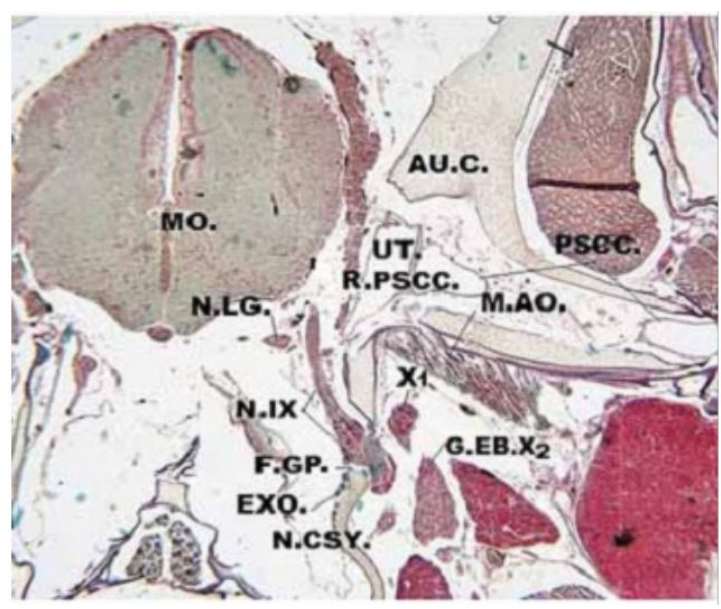

Figure 3. Photomicrograph of part of a transverse section of Oreochromis niloticus passing through the postorbital region showing the glossopharyngeal foramen. X40.

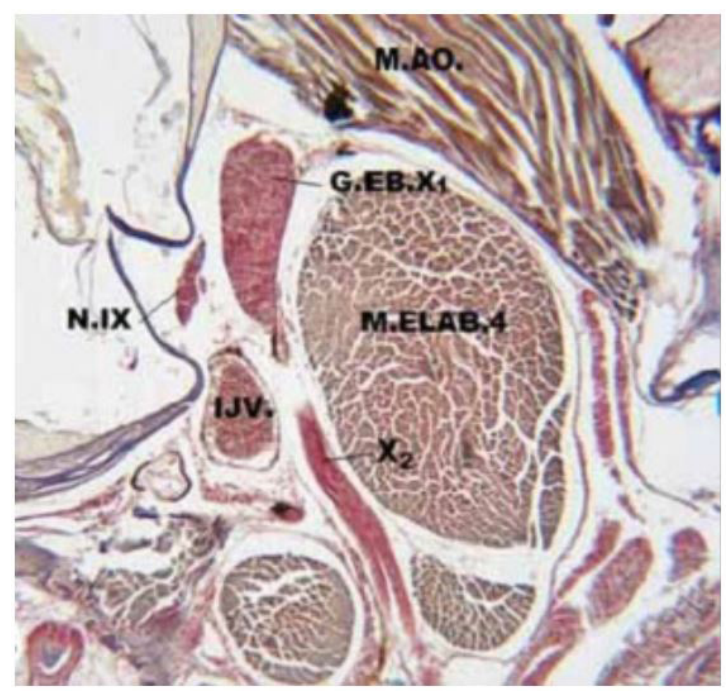

Figure 4. Photomicrograph of part of a transverse section of Oreochromis niloticus through the postotic region showing the position of the glossopharyngeal nerve extracranially. X60. AU.C. Auditory capsule. EXO. Exooccipital bone. F.GP. Glossopharyngeal foramen. IJV. internal jugular vein. G.EB.X. $\mathbf{X}_{1}$ The epibranchial ganglion of the $1^{\text {st }}$ branchial vagal trunk. G.EB.X $\mathbf{X}_{2}$ The epibranchial ganglion of the $2^{\text {nd }}$ branchial vagal trunk. MO. Medulla Oblongata. N.CSY. Cranial sympathetic nerve. N.IX Nervus glossopharyngeus RO.IX Glossopharyngeal root.

glossopharyngeus shifts ventromedially being ventral to the cranial sympathetic nerves, ventromedial to the origin of the first branchial vagal trunk and dorsomedial to the internal jugular vein. In this position, it gives off two fine branches to the first external levator arcus branchialis muscle (Figure 1, Nn.ELAB.1) and one fine branch to the first internal levator arcus branchialis muscle (Figure 1, N.ILAB.1). Then it enters the petrosal (epibranchial) ganglion (Figures 1, 5, G.P). This ganglion lies ventral to the cranial sympathetic nerve (N.CSY.), medial to the internal jugular vein (IJV.), dorsolateral to the circus cephalicus and the second epibranchial artery (EP.A2). From the epibranchial (petrosal) ganglion arise the nervus glossopharyngeus as two branches; the ramus pharyngeus (Figure 1, R.PH. IX) and the trunk representing the rami pretrematic and posttrematic IX, (Figures 1, 5, Rr.PT.+PR.IX).

\subsection{Ramus pharyngeus}

Ramus pharyngeus (Figure 1, R.PH.IX) arises anteriorly from the petrosal (epibranchial) ganglion. It runs for a long distance dorsal to the first external levator arcus branchialis muscle, ventral to the cranial sympathetic nerve and ventromedial to the internal jugular vein. Shortly forwards, ramus pharyngeus gives off a ventral branch which passes anteriorly and gives off a nerve ending in the gill chamber epithelial lining. Then that branch enters the psudobranch where it ends (Figure 1, N.PSB.). Anteriorly, ramus pharyngeus (Figure 6, R.PH.IX) continues forwards being dorsal to the pseudobranch (PSB), lateral to the efferent branchial artery, medial to the internal jugular vein and ventrolateral to the cranial sympathetic nerve. At the anterior end of the pseudobranch, it gives off two nerves for the pseudobranch (Figure 1, Nn.PSB.). Thereafter, ramus pharyngeus extends dorsal to the pharyngeal roof giving off a fine nerve to this roof. Shortly after that, the ramus pharyngeus extends dorsolateral to the roof of the pharyngeal cavity, where it divides into two nerves, which ramify in the epithelial lining of the pharyngeal roof.

\subsection{Rami pretrematic and posttrematic}

From the ventral side of the petrosal ganglion arise the two rami as a single trunk (Figures 1, 5, Rr.PT.+PR.IX). As the trunk leaves the ganglion, it receives a large sympathetic branch (Figures 1, 5, R.SY.IX). Thereafter, this trunk extends anteroventrally giving off a fine nerve to the first internal levator arcus branchialis muscle (Figure 1, N.ILAB.1). This trunk continues anteriorly being medial to the branchial lamellae and dorsolateral to the first epibranchial cartilage. Here, this trunk turns its course ventrolaterally in a posterior direction passing medial to the gill filaments where it gives rise to fine nerves to these filaments (Figure 1, Nn.GFM.). Shortly posteriorly and at the apex of the curvature of the first branchial arch, the trunk divides into its two rami; pretrematicus (R.PR.IX) and posttrematicus (R.PT.IX)(Figure 1).

\subsection{Ramus pretrematicus}

From the branchial trunk, ramus pretrematicus (Figures 1, 7, R.PR.IX) separates and runs venteromedially being ventral to the first epibranchial cartilage (C.EB.1), dorsal to the first ceratobranchial cartilage (C.CB.1) and medial to the gill rakers. Here, it gives fine branches to gill rakers and the epithelial tissue lining the first holobranch in this region (Figure 1, Nn.GR.+EP.L.). Directly after that, this ramus becomes dorsal to the ceratobranchial bone. It runs for a distance in this position giving rise to several fine branches to taste buds and the epithelium of the dorsal margin of the gill arch. Then, ramus pretrematicus (Figure 1, R.PR.IX) continues in the same position for a very long course during which it giving off many branches to the taste buds and epithelial lining of the gill arch. Finally, it ends as many fine nerves in the epithelial lining (Figure 1, Nn.EP.L.) of the floor of the pharynx and the taste buds in this region. 


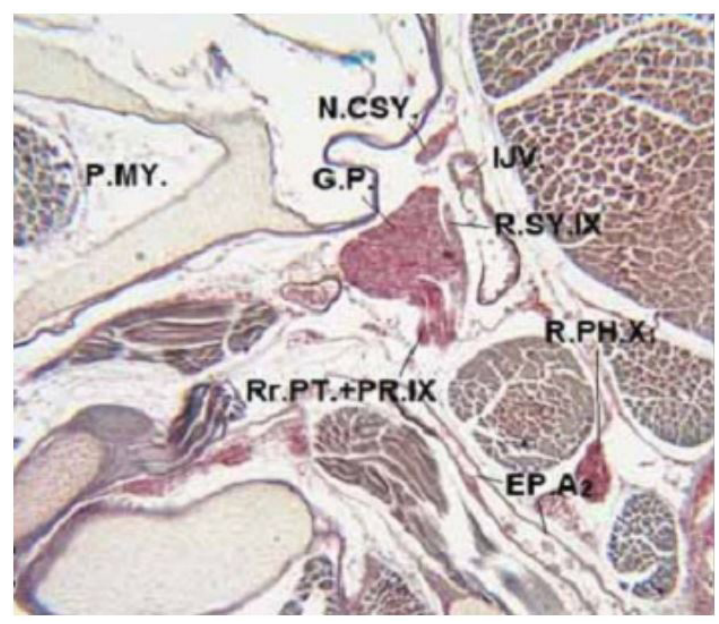

Figure 5. Photomicrograph of part of a transverse section of Oreochromis niloticus passing through the postotic region showing the petrosal ganglion and the origin of the rami pretrematic and posttrematic of nervus glossopharyngeus from the ganglion. The sympathetic nerve and sympathetic branch are also shown. X60.

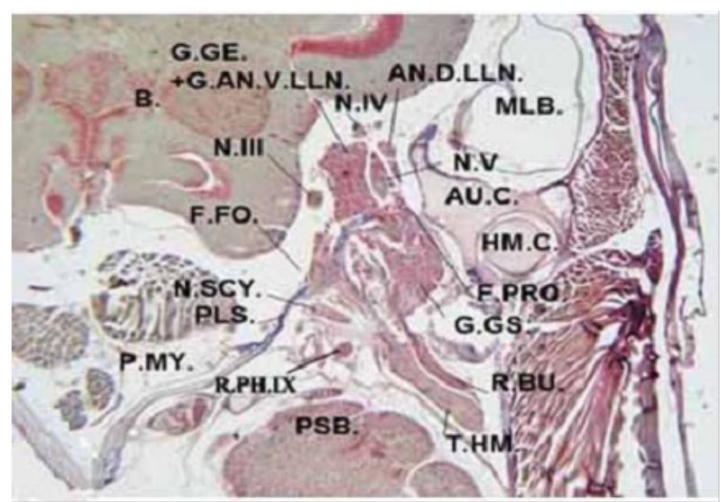

Figure 6. Photomicrograph of part of a transverse section of Oreochromis niloticus through the anterior otic region showing the position of ramus pharyngeus of the glossopharyngeal nerve. X40.

\subsection{Ramus posttrematicus}

From the branchial trunk, ramus posttrematicus (Figures 1, 7, R.PT.IX) separates and gives off a fine branch to the first adductor arcus brachialis muscle (Figures 1, 7, N.AAB.1). Then the main ramus extends ventrally lateral to the first epibranchial and ceratobranchial cartilages. It penetrates the first adductor arcus branchialis muscle and becomes ventrolateral to the ceratobranchial cartilage giving rise to fine posterior branches to the gill filaments and their muscles at the apex of the holobranch. Thereafter, the ramus posttrematicus runs anteriorly ventrolateral to the ceratobranchial cartilage and lateral to the efferent blood vessel. It runs for a long distance in this position giving off many branches to the muscles of the gill filaments (Figure 1, Nn.GFM.). More forwards, the ramus posttrematicus extends ventrolateral and then ventral to the first hypobranchial bone and dorsal to the afferent blood vessel. Here, it gives off many branches to the gill filament muscles (Figure 1, Nn.GFM.). Thereafter, it gives off several fine nerves to the gill filaments and their muscles.

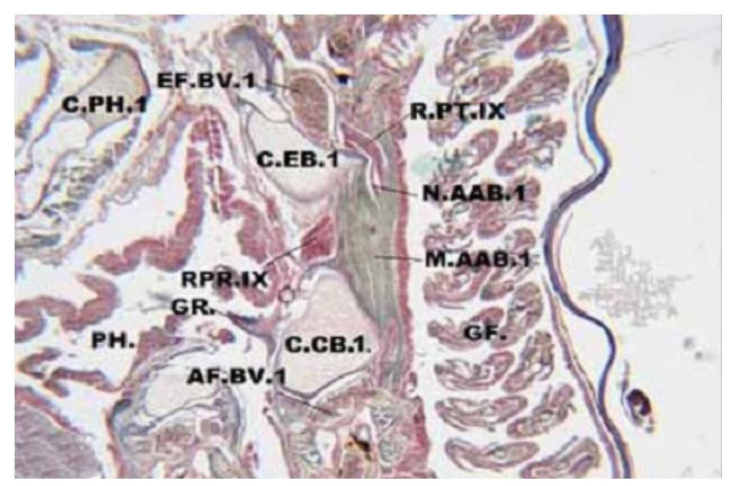

Figure 7. Photomicrograph of part of a transverse section of Oreochromis niloticus passing through the postotic region showing the separation of the rami pretrematicus and posttrematicus of nervus glossopharyngeus. The nerve to the adductor arcus branchialis is shown. X60. AU.C. Auditory capsule. B. Brain. C.CB.1 The first ceratobranchial cartilage. C.EB.1 The first epibranchial cartilage. EP. $\mathbf{A}_{2}$ The second epibranchial artery. G.P. Petrosal ganglion. GR. Gill Raker. IJV. internal jugular vein. M.AAB.1 First adductor arcus branchialis muscle. N.AAB.1 Nerve to the $1^{\text {st }}$ adductor arcus brachialis muscle. N.CSY. Cranial sympathetic nerve. PSB. Pseudobranch. R.PH.IX Ramus pharyngeus of nervus glossopharyngeus. R.PR.IX Ramus pretrematicus of nervus glossopharyngeus. R.PT.IX Ramus posttrematicus of the glossopharyngeal nerve. R.SY.IX Ramus sympathetic connecting the glossopharyngeal nerve. Rr.PT.+PR.IX Rami posttrematicus and pretrematicus of the glossopharyngeal nerve.

More forwards, it gives off a branch to the epithelium of the isthmus. Finally, it runs medially dorsal to the afferents branchial vessels and ventral to the basibranchial and hypobranchial cartilage till it ends in the first obliquus ventralis muscle (Figure 1, N.OV.I).

\section{Discussion}

In the species under investigation, nervus glossopharyngeus originates by a single root from the lateral side of the medulla oblongata. This was described in many teleosts (Dakrory and Ali, 2006; Dakrory et al., 2012, 2014, Al-Harthi, 2016). However, nervus glossopharyngeus arises by two roots as said by Maheswari (1965) in Mastacembelus armatus and Saxena (1967) in Amphipnous cuchia. Among Chondrichthyes, a single root was described by Mazhar (1979) in Pteroplatea altavela. However, Dakrory (2000) described three rootlets for nervus glossopharyngeus in Rhinobatus halavi, and they unite into one root soon.

Moreover, Matsuda et al. (1991) reported a single glossopharyngeal (postotic) nerve originates from the vagal lobe passing to the gills and pharynx. Also, Wicht (1996) in Ichthyomyzon unicuspis and Braun (1998) in the hagfishes Eptatretus stoutii and Myxine glutinosa found the same case. On the other hand, Kuratani et al. (1997) mentioned separate glossopharyngeal and vagal nerves in embryos of Lampetra japonica.

In 0 . niloticus, the glossopharyngeal nerve emerges from the cranial cavity through a separate foramen in the exoccipital bone. Also in Ctenopharyngodon idellus (Dakrory, 
2000), Tilapia zillii (Dakrory and Ali, 2006), Liza ramada (Dakrory et al., 2012) and Liza aurata (Al-Harthi, 2016), the same case was found. On the other hand, Dakrory et al. (2014) reported the exit of both the glossopharyngeus and the vagal nerves together from the cranium through the jugular foramen in Gambusia affinis affinis.

Nakae and Sasaki (2008) carried out studies on ten tetraodontiform families; they stated that the relation between the glossopharyngeal foramen and the elements of the cranium shows a wide range of variation. These authors showed that in Triacanthus biaculeatus, Kentrocapros aculatus and Ostracionimm aculatus, nervus glossopharyngeus exits from the cranium together with the vagal nerve through a foramen in the exoccipital bone, as previously mentioned. While the nerve leaves the cranial cavity through a foramen in the pterotic bone in Sufflamenchry sopterum and Zeus faber. However, in Canthigas terrivulata and Antigoni acapros, this nerve emerges from the cranium through a foramen in the posterior part of the prootic bone. In Diodon holocanthus, the glossopharyngeal nerve leaves the skull through an opening between the exoccipital and basioccipital bones. On the other hand, nervus glossopharyngeus and nervus vagus emerge through a foramen in the prootic bone in Molamola. In Lophiomus setigerus, nervus glossopharyngeus emerges from the cranium through a foramen rimmed by the prootic, exoccipital and basioccipital bones. In Malakichthy swakiyae and Siganus spinus, the glossopharyngeal nerve leaves the cranium through a foramen in the exoccipital bone.

The case is different in cartilaginous fishes. Many authors such as, Hamdy and Hassan (1973), Elsatti (1982) and Dakrory (2000), described a canal through which the glossopharyngeal nerve passes. This glossopharyngeal canal is communicated with the auditory capsule cavity.

In the species studied, only one, extracranially located, petrosal (epibranchial) ganglion is present. The same case was reported in some teleosts by many authors, such as de Graaf, (1990) in Cyprinus carpio, Dakrory, (2000) in C. idellus, Dakrory and Ali (2006) in T. zillii, Hussein (2010) in Mugil cephalus, Dakrory et al. (2012) in L. ramada, Dakrory et al. (2014) in G. affinis affinis and Al-Harthi (2016) in L. aurata. Whereas, two ganglia; a medial intracranial sensory ganglion and a lateral petrosal intracranial one, were found for the glossopharyngeal nerve by Northcutt and Bemis (1993) in Latimeria chalumnae and Piotrowski and Northcutt (1996) in Polypterus senegalus.

In 0 . niloticus, there is no connection between the glossopharyngeal and the octaval nerves or its branches. However, Harrison (1981) described a connection between nervus glossopharyngeus and ramus ampularis posterior in Trichiurus lepturus.

In the present study, nervus glossopharyngeus has three rami; pharyngeus, pretrematic and posttrematic rami, distal to the petrosal ganglion. The same case is confirmed by Harrison (1981) in T. lepturus, De Graaf (1990) in C. carpio, Piotrowski and Northcutt (1996) in P. senegalus and by Dakrory and Ali (2006) in T. zillii. However, ramus pharyngeus is lacking and only two rami is present in many cases as those reported by Hussein (2010) in M. cephalus, Dakrory et al. (2012) in L. ramada, Dakrory et al. (2014) in G. affinis affinis and by Al-Harthi
(2016) in L. aurata. Moreover, Dakrory (2000) and Taha (2010) reported the lacking of ramus pretrematicus in C. idellus and Hypophthalmichthys molitrix, respectively, i.e. there are two rami; ramus pharyngeus and ramus posttrematicus.

Regarding cartilaginous fishes, Dakrory (2000) described three rami; pharyngeus, pretrematicus and posttrematicus for the glossopharyngeal nerve in $R$. halavi.

In the studied cichlid species, there is no connection between the glossopharyngeal and the facial nerves. This case was mentioned by Dakrory and Ali (2006) in T. zillii, Hussein (2010) in M. cephalus, Dakrory et al. (2012) in $L$. ramada, Dakrory et al. (2014) in G. affinis affinis and by Al-Harthi (2016) in L. aurata. On the other hand, there is a connection between ramus pharyngeus IX and the posterior palatine ramus of the facial nerve (Jacobson's anastomosis) was reported in C. idellus (Dakrory, 2000) and in H. molitrix (Taha, 2010). Also, ramus pharyngeus IX was reported to be connected with the rostral pole of the facial ganglion in P. senegalus (Piotrowski and Northcutt, 1996). Moreover, Saxena (1967) and Harrison (1981) described a connection between the glossopharyngeal and the facialis nerves in A. cuchia and T. lepturus, respectively.

In the species under investigation, ramus posttrematicus is not divided into two parts. The same condition was described by Dakrory (2000) in C. idellus, Dakrory and Ali (2006) in T. zillii, Taha (2010) in H. molitrix, Dakrory et al. (2012) in L. ramada, Dakrory et al. (2014) in G. affinis affinis and Al-Harthi (2016) in L. aurata. On the other hand, this ramus is divided into two parts; anterior and posterior as reported by Northcutt and Bemis (1993) in L. chalumnae and by Piotrowski and Northcutt (1996) in P. senegalus.

\section{Conclusion}

From the above-mentioned data, it is clear that there are some differences in the glossopharyngeal nerve of the studied species, concerning anatomy and number of nerve rami. On the other hand, there are similarities in certain features as root, ganglion and type of fibers. So we can conclude that, although there is a specific variation in the nerve among bony fishes; yet it is a typical branchial nerve.

\section{Acknowledgments}

The authors are grateful to the Deanship of Scientific Research for funding this article by Taif University Research Supporting Project number (TURSP-2020/119), Taif University, Taif, Saudi Arabia.

\section{References}

ABOUGABAL, K.M., MOSELHY, W.A. and KORNI, F.M.M., 2020. The effect of cadmium toxicity on Oreochromis niloticus and human health. African Journal of Aquatic Science, vol. 45, no. 3, pp. 303-309. http://dx.doi.org/10.2989/16085914.2019.1707429.

AL-HARTHI, D.A., 2016. Comparative anatomical studies on the cranial nerves of Liza aurata (Osteichthyes - Mugilidae). Kingdom of 
Saudi Arabia, KSA: Faculty of Science, Taif University, Master's Thesis in Zoology.

ALI, R.S. and DAKRORY, A.I., 2008. Anatomical studies on the cranial nerves of Alticus kirkii magnosi. I. The eye muscle nerves and the ciliary ganglion. Egyptian Journal of Zoology, vol. 51, pp. 221-239.

AL-MALKI, G.J., 2017. Anatomical studies on the cranial nerves of Oreochromis niloticus (Osteichthyes - Cichlidae). Kingdom of Saudi Arabia, KSA: Faculty of Science, Taif University, Master's Thesis in Zoology.

BRAUN, C.B., 1998. A new craniate chemosensory modality in hagfishes. The Journal of Comparative Neurology, vol. 392, no. 2, pp. 135-163. http://dx.doi.org/10.1002/ (SICI)1096-9861(19980309)392:2<135::AID-CNE1>3.0.CO;2-3. PMid:9512266.

DAKRORY, A.I. and ALI, R.S., 2006. Comparative anatomical studies on the cranial nerves of Tilapia zillii. The Nervus Glossopharyngeus. Journal of The Egyptian-German Society of Zoology, vol. 49, no. B, pp. 1-18.

DAKRORY, A.I., 2000. Comparative anatomical studies on the cranial nerves of Rhinobatus halavi (class: Chondrichthyes) and Ctenopharyngodon idellus (class: Osteichthyes). Egypt: Faculty of Science, Cairo University, Philosophy Doctor Thesis in Comparative Anatomy, Zoology.

DAKRORY, A.I., 2003. The ciliary ganglion and its anatomical relations in some bony fishes. Egyptian Journal of Zoology, vol. 4, pp. 1-13.

DAKRORY, A.I., ABDEL-KADER, T.G. and MATTAR, S.F.E., 2014 Anatomical studies on the cranial nerves of the fully formed embryonic stage of Gambusia affinis affinis (Baird \& Girard, 1853). II. Nervus glossopharyngeus. International Journal of Advanced Research, vol. 2, no. 8, pp. 728-736.

DAKRORY, A.I., ALI, H.M., ALI, R.S., ABDEL-KADER, T.G. and MAHGOUB, A.F., 2018. Innervation of the gill region of Garra tibanica (Trewavas, 1941) From Taif KSA (OsteichthyesCyprinidae). I- Nervus Glossopharyngeus. Sylwan, vol. 162, no. 4, pp. 104-137.

DAKRORY, A.I., ALI, R.S. and ISSA, A.Z., 2012. Anatomical studied on the cranial nerves of Liza Ramada (Family: Mugilidae) nervus Glossopharyngeus. Life Science Journal, vol. 9, no. 2, pp. 86-93.

DE GRAAF, P.J., 1990. Innervation pattern of the gill arches and gills of the carp (Cyprinus carpio). Journal of Morphology, vol. 206, no. 1, pp. 71-78. http://dx.doi.org/10.1002/jmor.1052060108. PMid:29865757.

EL-SATTI, F.M., 1982. Studies on the head skeleton of Selachii. Egypt: Faculty of Home economic, Helwan University, Philosophy Doctor Thesis in Zoology.

HAMDY, A.R. and HASSAN, S.H., 1973. On the neurocranium of Torpedo ocellata. Bulletin of Faculty of Science, Cairo University, vol. 46, pp. 127-136.

HARRISON, G., 1981. The cranial nerves of the teleost Trichiurus lepturus. Journal of Morphology, vol. 167, no. 1, pp. 119-134. http://dx.doi.org/10.1002/jmor.1051670111. PMid:30139195.

HUSSEIN, A.K., 2010. Anatomical studies on the cranial nerves of Mugil cephalus (Family: Mugilidae). Egypt: Faculty of Science, Cairo University, Master's Thesis in Zoology.

JONZ, M.G. and NURSE, C.A., 2008. New developments on gill innervation: insights from a model vertebrate. The Journal of Experimental Biology, vol. 21, no. Pt 15, pp. 2371-2378. http:// dx.doi.org/10.1242/jeb.010587. PMid:18626070.

KEREM, G., YOSHIMOTO, M., YAMAMOTO, N., YANG, C.Y., XUE, H.-G. and ITO, H., 2005. Somatotopic organization of the trigeminal ganglion cells in a cichlid fish, Oreochromis (Tilapia) niloticus.
Brain, Behavior and Evolution, vol. 65, no. 2, pp. 109-126. http:// dx.doi.org/10.1159/000082980. PMid:15627723.

KURATANI, S., UEKI, T., AIZAWA, S. and HIRANO, S.1997. Peripheral development of the cranial nerve in a cyclostome, Lampetra japonica: morphological distribution of nerve branches and vertebrate body plan. The Journal of Comparative Neurology, vol. 384, no. 4, pp. 483-500. http://dx.doi.org/10.1002/ (SICI)1096-9861(19970811)384:4<483::AID-CNE1>3.0.CO;2-Z. PMid:9259485.

MAHESWARI, S.C., 1965. The cranial nerves of Mastacembelus armatus (Lacépéde). Japanese Journal of Ichthyology, vol. 12, no. 3-6, pp. 89-98.

MATSUDA, H., GORIS, R.C. and KISHIDA, R., 1991. Afferent and efferent projections of the glossopharyngeal-vagal nerve in the hagfish. Journal of Comparative Neurology, vol. 311, no. 4, pp. 520530. http://dx.doi.org/10.1002/cne.903110407. PMid:1757601.

MAZHAR, F.M., 1979. The elasmobranch of the Mediterranean. V. the ray Pteroplatea altavela (Linn.). Proceedings of the Zoological Society, Egypt, vol. 6, pp. 117-131.

MEADER, R.G., 2005. The innervation of the muscle of accommodation in the eye of the teleost, Holocentrus ascensionis. Journal of Morphology, vol. 59, no. 1, pp. 163-172. http://dx.doi. org/10.1002/jmor.1050590108.

NAKAE, M. and SASAKI, K., 2008. Branchial arch muscle innervation by the glossopharyngeal (IX) and the vagal (X) nerves in Tetraodontiformes, with special reference to muscle homologies. Journal of Morphology, vol. 269, no. 6, pp.674-690. http://dx.doi. org/10.1002/jmor.10611. PMid:18431808.

NILSSON, S. 1984. Innervation and pharmacology of the gills. In: W. S. Hoar and D. J. Randall, editors. Fish physiology. San Diego: Academic Press, vol. 10, pt A, pp. 185-227. http://dx.doi. org/10.1016/S1546-5098(08)60319-2.

NORTHCUTT, R.G. and BEMIS, W.E., 1993. Cranial nerves of the coelacanth, Latimeria chalumnae (Osteichthyes: Sarcopterygii: Actinista), and comparisons with other craniates. Brain, Behavior and Evolution, vol. 42, no. suppl. 1, pp. 1-76. http://dx.doi. org/10.1159/000114175.

PIOTROWSKI, T. and NORTHCUTT, R.G., 1996. The cranial nerves of Senegal bichir, Polypterus senegalus (Osteichthyes: Actinopterygii: Cladistia). Brain, Behavior and Evolution, vol. 47, no. 2, pp. 55-102. http://dx.doi.org/10.1159/000113229. PMid:8866706.

SAPARUDDIN, S., YANTI, Y., SALIM, S. and MUHAMMAD, H., 2020. Hematological response of Tilapia (Oreochromis niloticus) in Laundry wastewater. Biogenesis Jurnal Ilmiah Biologi., vol. 8, no. 1, pp. 68-77. http://dx.doi.org/10.24252/bio.v8i1.13137.

SAXENA, P.K., 1967. The cranial nerves of the mudeel Amphipnous cuchia. Acta Anatomica, vol. 67, no. 2, pp. 306-320. http://dx.doi. org/10.1159/000143036. PMid:5587522.

SNEDDON, L.U., 2003. Trigeminal somatosensory innervation of the head of a teleost fish with particular reference to nociception. Brain Research, vol. 972, no. 1-2, pp. 44-52. http://dx.doi. org/10.1016/S0006-8993(03)02483-1. PMid:12711077.

SUNDIN, L. and NILSSON, S., 2002. Branchial innervation. Journal of Experimental Zoology, vol. 293, no. 3, pp. 232-248. http:// dx.doi.org/10.1002/jez.10130. PMid:12115899.

TAHA, F.K., 2010. Anatomical studies on the cranial nerves of the fish Hypophthalmichthys molitrix. Egypt: Faculty of Science, Cairo University, Master's Thesis in Zoology.

WICHT, H., 1996. The brains of Lampreys and Hagfishes: characteristics, characters and comparisons. Brain, Behavior and Evolution, vol. 48, no. 5, pp. 248-261. http://dx.doi. org/10.1159/000113204. PMid:8932866. 